\title{
Developing an integrated land use planning system on reclaimed wetlands of the Hungarian Plain using economic valuation of ecosystem services
}

\author{
Zsolt Pinke $^{\mathrm{a}, *}$, Márton Kiss ${ }^{\mathrm{b}, \mathrm{c}}$, Gábor L. Lövei ${ }^{\mathrm{d}}$ \\ a Department of Nature Conservation and Landscape Ecology, Szent István University, Páter Károly utca 1, H-2100 Gödöllö, Hungary \\ ${ }^{\mathrm{b}}$ Department of Climatology and Landscape Ecology, University of Szeged, Egyetem u. 2, H-6722 Szeged, Hungary \\ ${ }^{\mathrm{c}}$ MTA Centre for Ecological Research, Klebelsberg K. u. 3, H-8237 Tihany, Hungary \\ ${ }^{\mathrm{d}}$ Department of Agroecology, Aarhus University, Flakkebjerg Research Centre, Forsøgsvej 1, DK-4200 Slagelse, Denmark
}

\section{A R T I C L E I N F O}

\section{Article history:}

Received 19 April 2017

Received in revised form 28 July 2017

Accepted 18 September 2017

Available online $\mathrm{xxxx}$

\section{Keywords:}

Greening CAP

Landscape planning

Land use conversion

Suitability

Wetland restoration

\begin{abstract}
A B S T R A C T
The establishment of a sustainable land use system is crucial in Hungary (SE Europe) where $30 \%$ of croplands lie on former floodplains, and $40-45 \%$ of arable lands are drought-prone. We calculated and compared the monetary value of the main wetland ecosystem services, the profitability of land use and the additional costs of grain producer system on land at risk from groundwater inundation on the Hungarian Plain. We show that orchards and forestry generate a much higher profitability in former wetlands than cropland farming. Using the replacement cost method, we prove that the reservoir capacity of restored wetlands with an ecologically optimal $0.5 \mathrm{~m}$ water depth could replace $2150 \mathrm{Eha}^{-1}$ flood protection investment cost. The calculated costs of protecting land under the two highest groundwater risk categories between 1999-2005 was $260.2 € \mathrm{ha}^{-1} \mathrm{y}^{-1}$ and $104.1 € \mathrm{Ch}^{-1} \mathrm{y}^{-1}$, respectively. Although the flood protection benefits of former wetlands may provide an appropriate value base for restoration per se, combined with the potential advantages of land use change from cropland to forest in former wetlands and the carbon sequestration benefit provide 'win-win' solutions for land users and institutional actors interested in flood prevention, environmental protection and climate mitigation.
\end{abstract}

(ㄷ) 2017 Elsevier B.V. All rights reserved.

\section{Introduction}

With the increasing numbers of humankind, there are increasing pressures on natural areas that can be converted to "productive" uses (Gliessman, 2015). Production-centered approaches consider that the large-scale conversion of natural habitats brings overwhelming benefits, or at least they are unavoidable, and overall, useful for people. This perception has resulted in large-scale habitat conversion that gained speed during the 20th century, with its large-scale mechanisation. As part of this process, many of the continent's rivers were regulated, their courses shortened and straightened, and former floodplains drained and converted to cropland (Pfadenhauer and Grootjans, 1999). The same happened in the central part of the Carpathian Basin (SE Europe) that historically had up to $25 \%$ of its area under temporary or permanent inundation, but ca. $98 \%$ of these wetlands has been converted to croplands (Koncsos, 2011).

\section{* Corresponding author.}

E-mail addresses: pinkezsolt@gmail.com (Z. Pinke), kiss.marton@geo.u-szeged. hu (M. Kiss), gabor.lovei@agro.au.dk (G.L. Lövei).
However, provisioning services (e.g. food production; see Table 3) are only one class of ecosystem services (de Groot et al., 2002), and in order to achieve sustainability, other functions and services have also to be evaluated. Human land use activities including agriculture, forestry and energy production are the major anthropogenic greenhouse gas (GHG) emitters (IPCC, 2014). This effect makes habitats that can capture and retain carbon (carbon sinks) very important. Wetlands are habitats with very high carbon storing capacity, to an estimated $830 \mathrm{Tg} \mathrm{y}^{-1}$ (Mitsch et al., 2012), but they suffered severe losses globally during the recent transformation of agriculture. Their conversion to arable lands, pastures or artificial surfaces are greatly responsible for global carbon emission of land use (Watson et al., 1995). As a feedback, growing hydroclimatic vulnerability, increasing temperatures and worsening droughts on temperate plains pose a major challenge for land use policy and food security (Ray et al., 2015). With the growing awareness and acceptance of the contribution of ecosystem services to human welfare (The Economics of Ecosystems and Biodiversity, (TEEB) 2010), the value of the former natural areas can now be conceptualised, articulated and better evaluated. In this contribution, we use the example of the croplands on areas formerly under 
inundation on the lowlands of Hungary to show that integrated modelling approaches can improve the sustainability assessment of coupled ecological-economic systems. In particular, we shall argue that through restoring former wetlands currently under unprofitable cropland farming, most of the investment costs of a billion-euro flood protection megaproject in the Hungarian Plain can be saved. We claim that the re-evaluation of communal benefits is a key factor in the implementation of a sustainable land use system. Finally, we propose a zonal land use system that may support social adaptation to the landscape conditions of the once mosaiclike floodplain structure and to the challenge of climate change. Such an integrated perspective is important to support environmental and nature conservation policies and can contribute to current Mapping and Assessment of Ecosystems and their Services (Maes et al., 2012) and TEEB (2010) initiatives.

As a result of climatic, geomorphological and hydrological conditions, $25.3 \%$ of the 4.3 million ha of Hungarian arable lands is vulnerable to groundwater flooding (River Basin Management Plan of Hungary - RBMPH, 2010). An extensive canal system protects these arable lands that lie on former wetlands; they channelled an average of $1.77 \times 10^{9} \mathrm{~m}^{3} \mathrm{y}^{-1}$ of groundwater into the river system between 1982 and 2006 (Hungarian Hydrological Yearbooks, 1983-2007).

Additionally, the majority of these drained wetlands are in areas that are the worst affected by droughts (Pálfai, 2004). Risk from groundwater floods is highest in January-March and in June, periods that coincide with the peak of floods. The high waters in June, however, precede the drought-prone summer months. Therefore, the drainage of former wetlands increased the flood risk on such reclaimed lands, and created new arable lands exposed to drought risk. To mitigate the hydroclimatic vulnerability of dry plains, extensification in agriculture (Olesen and Bindi, 2002) and the restoration of former wetlands (Csete et al., 2011; Hungarian Climate Change Strategy - HCCS, 2013; Hungarian Water Strategy HWS, 2015) are suggested.

According to the Hungarian Water Strategy (2013, 2015), lowlying areas with low agro-ecological potential, which are regularly affected by groundwater flooding and where protection from this threat is disproportionately expensive, must be withdrawn from arable farming and water retention is to be encouraged on them instead. On the northern part of the Great Hungarian Plain, the relevant management plan (RBMP of Tisza, 2010) recommends the creation of protective puffer zones along $90 \%$ of streams, land use conversion in areas sensitive to nitrate pollution, and water body rehabilitation along more than $70 \%$ of the small and mediumsized streams.

The current river and groundwater flood protection system of the Hungarian Plain was established during the 19th-20th century agro-modernisation (Pinke, 2014). Today, $2940 \mathrm{~km}$ of dykes and $42,600 \mathrm{~km}$ of canals protect low-lying lands from groundwater flooding (Somlyódy, 2011). The sustainability of this extensive dyke and channel system was put to the test by extreme hydrological events in the late 1990s, just when Hungarian agriculture left governmental protectionism behind for the first time since the late 19th century (Morkre and Tarr, 1995; Kopsidis, 2008). The recognition that, under the conditions of post-communist market economy, revenues from farming are unable to finance the flood defence of such low-lying arable lands generated a paradigm change in Hungarian landscape ecology and water management (Szlávik, 2000). Although agro-experts, environmentalists, hydrologists and spatial planners recognised the necessity of restoring formerly reclaimed wetlands (VATI, 2004), due to the lack of well-established economic strategies for wetland utilization including detailed assessments of the ecosystem services, public dispute turned into polemics of an almost religious intensity (Koszorú and Szántó, 2011).

Participants of this intense debate were unable to reach a consensus on the size of areas to be involved in wetland restoration.
These disputes highlighted two very important facts. First, agricultural and economic planners could not (or were not willing to) redefine the traditional land use approach, in which 'wetlands were viewed as a waste of valuable land that could only be improved through drainage and destruction of the wetland' (Woodward and Wui, 2001). Second, the profits from cultivating these lands prone to groundwater flooding cannot cover the protection costs and water hazards, which discredited the sustainability of the present land use and water management systems (Forgóné Nemcsics, 2000; HCCS, 2013; HWS, 2015).

Hydrological planning reduced the complexity of ecological, social and economic aspects of hydroclimatic vulnerability of the lowlands to a simple flood protection plan (Vásárhelyi Development Plan - hereafter VDP, 2004), suggesting the creation of overflow reservoirs with ca. 700 million $\mathrm{m}^{3}$ storage capacity (Table 5). However, long term flood security in the Tisza Basin requires retaining ca. $1.5-2$ billion $\mathrm{m}^{3}$ of water during flood peaks (VATI, 2004; Koncsos, 2006). Reserving this amount of water in a small area selected for this purpose (Table 5) can only be achieved by relatively deep reservoirs protected by dykes. The land use in these emergency reservoirs is dominated by crop farming, but the crop cannot survive when the reservoir is flooded to several $m$ depth. So, the government is expected to compensate the land users of these reservoirs after each flood event. The concept was widely criticised, because it disregarded economic, ecological and geomorphological considerations (Gábris et al., 2004; Ungvári and Kiss, 2013). A cost-benefit analysis found that water retention in 19 low-lying floodplain locations along the Tisza River (Fig. 1), assuming a $1.5-2.5 \mathrm{~m}$ deep water in them, plus raising the height of the dyke system by $0.5 \mathrm{~m}$ above the critical flood level would be a far cheaper solution than implementing the VDP (Koncsos, 2006).

Retaining billions of $\mathrm{m}^{3}$ of water infiltrating into the soil and evaporating in a wetland system may greatly reduce flood and drought risk on dry continental plains (Kerekes et al., 1994). Due to the prohibitively high investment and maintenance costs of flood defence systems, flood protection services provided by wetlands have outstandingly high value (Stürck et al., 2014; Mitsch and Gosselink, 2015; National Flood Resilience Review, 2016). Thus, we hypothesised that the flood defence service could be a core factor to integrate global and local targets, including food security and carbon capture in an ecologically and economically sustainable land use system in the drought-prone parts of the Hungarian Plain.

Economic undervaluation of the ecosystem services provided by wetlands (Clare et al., 2011) is a crucial factor hindering their conservation, maintenance and restoration. To improve this situation and move towards an integrative land use planning in the floodand drought-prone Hungarian Plain, we assessed the value of two important wetland-related ecosystem services (flood protection, carbon sequestration in floodplain forests), and compared them to the value of the relevant provisioning services (livestock, crop and timber production) and the additional groundwater flood protection costs of the current grain producer land use system.

\section{Materials and methods}

\subsection{Study area}

The $9331 \mathrm{~km}^{2}$ large study area lies in the centre of the Hungarian Plain, east of the Tisza River (Fig. 1). Almost half of the areas highly prone to groundwater flooding and one-third of the areas with the highest drought frequency and intensity in Hungary is concentrated here (Fig. 1). These flood-prone surfaces cover $59.6 \%$ of the study area; additionally, $30.8 \%$ of the landscape is also affected by salinization. This lowland region is one of the largest 


\section{دريافت فورى ـ ـ متن كامل مقاله}

\section{ISIArticles}

مرجع مقالات تخصصى ايران

ل امكان دانلود نسخه تمام متن مقالات انكليسى ل امكان دانلود نسخه ترجمه شده مقالات ل يذيرش سفارش ترجمه تخصصى $\checkmark$ ل امكان جستجو در آرشيو جامعى از صدها موضوع و هزاران مقاله ل امكان دانلود رايكان r صفحه اول هر مقاله

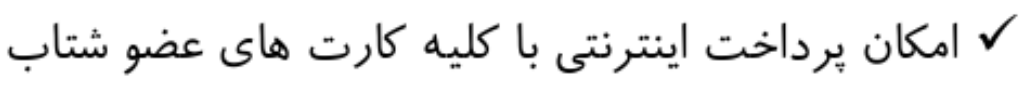
ل دانلود فورى مقاله پِ از برداخت آنلاين

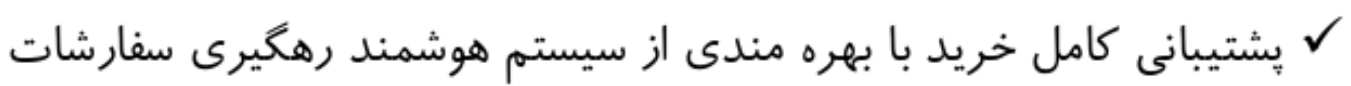

